\title{
London bites private bullet publicly
}

\section{University cuts}

\section{spending across}

\section{the board}

The University of London last week let its constituent colleges know how much they will have to spend next year, and how many students they will be permitted to educate three years from now, in 1983-84. The target reductions of the student population are in line with the gloomier forecasts; most culleges are disappointed with their financial allocation for the academic year immediately ahead.

Some, however, are relieved. Earlier this year, Chelsea College, one of the sciencebased smaller colleges in the university, was singled out by the second interim report of the Committee on Academic Organization commissioned by the university for oblivion or dismemberment; Chelsea is therefore understandably relieved that the now threatened reduction of its student numbers three years hence is a mere 14 per cent.

Other colleges, previously thought to be set fair, have been downcast. Queen Elizabeth College, for example, applauded in the most recent interium report of the Committee on Academic Organization (under Sir Peter Swinnerton-Dyer) has been asked to plan for a student body reduced by a third three years from now. The reduction is even more drastic than that decred by the University Grants Committee for the University of Aston in Birmingham.

Under the university's plan for the cutting of the cake for the coming academic year, the larger colleges do best. University College London, singled out for its high unit costs, by the Swinnerton-Dyer Committee, will have to stomach only a five per cent cut in student numbers in the next five years.

In its letter to schools of the university last week, the Court said that it had decided to take full account of the recently decreed increase of fees for part-time students, but had made a special but interim provision for Birkbeck College (most of whose students are part-time). On overseas students (or the lack thereof) the Court said that it could not undertake to help those branches of the university hard-hit by recent changes.

The Court's letter contains an element of second guessing in the statement that it has "devised arithmetical values for the various UGC verbal indications about Arts and Sciences". The upshot of the Court's calculation seems to be that, after allowing for the buoyant future spelled out for Imperial College, the population of science

students in the rest of the university will decrease by 11.3 per cent in the next three years, compared with the reduction of 5.7 per cent expected in other academic fields.

The university court seems, nevertheless, to have been perplexed by some of the consequences of its arithmetic. Given the substantial reduction of student numbers in science foreseen, and the grants committee's recommendation (to the university as a whole) that special attention should be given to veterinary science, mathematics and engineering, the Court records that it enquired whether a reduction was required in biology.

Apparently it "emerged" that the committee had not intended that the

\section{Soviet Union urges space demilitarization}

The Soviet Union has proposed a new treaty banning the deployment of weapons in outer space. The terms of the treaty, set out in a letter from the Soviet Foreign Minister, Andrei Gromyko, to the Secretary General of the United Nations, Dr Kurt Waldheim, differs from the 1967 treaty on outer space in two important respects. It covers all weapons, and is envisaged as an instrument of the United Nations, to be available for signature by "all states" with the instruments of ratification deposited with the United Nations Secretary General and not, as in 1967 with individual sponsoring governments. Accordingly, in the opening clauses of the draft, the text, refers to "member states" and switches to "signatories" only in details dealing with the technicalities of ratification, amendment and possible withdrawal. According to TASS, the essential articles of the draft read as follows:

1.1 The member states undertake not to put into orbit around the Earth objects bearing weapons of any kind, not to install such weapons on celestial bodies, and not to deploy any weapons in outer space in any other way including on piloted spacecraft of multiple use both of the existing type and also of other types which may be developed in the future by member states.

1.2 Each member state . . . undertakes not to help, encourage and incite any state, group of states or international organization to engage in activities running counter to the provisions of paragraph 1 of the present article.

2 . The member states shall use spacecraft in strict accordance with international law including the UN Charter in the interests of maintaining international peace and security, and for the development of international cooperation and mutual understanding.

3. Each member state shall be bound not to destroy, damage or disturb the normal functioning or alter the flight trajectory of space vehicles of other signatories.

4. For the purpose of ensuring confidence in the observation of the provisions of the present treaty, each member state shall use subject group of "biological sciences" should "suffer such a large reduction" but that the committee was in favour of a reduction of the numbers of students following degree courses combining two science subjects, "a category not specifically mentioned in the UGC letters".

On balance, the Court has planned for a real reduction of 5 per cent in its resources in the coming academic year. Given previous commitments to medical and other professional schools in the university, the Court says that the generality of its dependants will have to make do with 7.5 per cent less in the coming academic year.

the national technical monitoring facilities at its disposal in such a way as to comply with the generally accepted principles of international law.

The document is, of course, only a draft, and with the United States toying with orbital laser weapons seems unlikely to achieve anything concrete in the near future. The US shuttle, however, and its possible military implications have been causing considerable concern to Soviet military experts. The past few months have seen numerous comparisons in the Soviet media between the "militarist"' capabilities of the shuttle and the essentially peaceable nature of the Soviet Salyut orbital stations. Such concern seems, at least in part, to lie behind Mr Gromyko's letter to Dr Waldheim, which notes that the risk of the militarization of outer space has "recently increased".

If the treaty should materialize, several ambiguities in Mr Gromyko's draft would doubtless have to be resolved. Thus article 3 , as it stands, seems to leave open two justifications for damaging or disturbing a spacecraft in flight - that it was not (or was erroneously thought not to be) the property of a member state, or that it was allegedly launched in breach of article 1.1. Again, the draft contains no clear definition of a "weapon". In its strictest sense, article 1.1 would preclude even the carrying of a hand gun or life-preserver by, say, senior of ficers of a large space station. Such a station, too, might well wish to deploy small rockets with explosive warheads to destroy artificial debris or meteors on a dangerous approach course. Would such rockets be classed as "weapons" if they were "accidentally" launched against the spacecraft of another signatory? Moreover, just as in 1967, the treaty makes no provision for inspection, simply calling (article 4.3 ) for consultations and exchange of information "where necessary". Without such provisions, any such treaty would be little more than an ethical gesture. 